\title{
Survival Psychology in Kevin Powers' The Yellow Birds
}

\author{
M Ikbal M Alosman ${ }^{a}$ \\ meqbal1980@yahoo.com \\ Department of English Language and Literature, \\ Avrasya University, Turkey \\ Raihanah M.M. ${ }^{b}$ \\ raihanah@ukm.edu.my \\ Faculty of Social Sciences and Humanities, \\ National University of Malaysia (UKM)
}

\begin{abstract}
After experiencing the American war in Iraq as a machine gunner in the U.S. Army, Kevin Powers deliberates on war and the risks surrounding the lives of all those involved in his debut novel, The Yellow Birds. This paper aims to uncover the survival psychology that underlies the behaviour of the two main characters in the novel, Private John Bartle and Private Daniel Murphy as well as other minor characters. Survival psychology expounds unpredictable and threatening situations where people's lives are at stake. They either choose to fight, flight or freeze in reaction to these horrible experiences, that is, they either take action, surrender or eventually die. In the context of war, soldiers frequently face such deadly situations. The reactions of the characters to the circumstances of war and their success and/or failure to cope with its dangers are indicative of their survival mechanism. The novel is examined according to the three major periods of impact in survival psychology, specifically, pre-impact, impact and post-impact periods. Bartle overcomes the psychological consequences of his war experience years after leaving the army, but Murphy loses his faculties in the chasms of war and consequently dies. The psychological survival of those who overcome these risks physically is not guaranteed. Such terrifying experiences of death may make these people vulnerable and exposed to psychological repercussions such as psychosis.
\end{abstract}

Keywords: survival psychology; psychoanalysis; Kevin Powers; The Yellow Birds; war

\section{INTRODUCTION}

After serving in the U.S. Army in Iraq as a machine gunner in 2004, Kevin Powers employs his war experience to write his very first novel, The Yellow Birds. Since its first publication in 2012, Powers' novel has received critical acclaim, including being shortlisted for the National Book Award. Many reviewers have celebrated the book to the point that it is compared to the classic novel by Stephen Crane, The Red Badge of Courage (Marzillier, 2013). Mitchell (2012: n.p.) describes The Yellow Birds as a superlative and 'shot through with greatness.' Similar sentiments are shared by numerous reviewers who describe it as a remarkable and extraordinary first novel (Kakutani, 2012), 'a masterpiece of war literature' (Mantel, 2012: n.p.) and 'the first American literary masterpiece' on the war in Iraq (Tobar, 2012: n.p.). In an interview with The Guardian, Eggers (2013: n.p.) considers The Yellow Birds as gorgeous, 'the best thing I've read about the war in Iraq and by far, the best novel.'

The Yellow Birds conveys the sound, smell and sight of war that are rarely narrated with such clarity and authenticity. It fathoms the psychological and moral implications of war on all

a (Main author)

$b$ (Corresponding author) 
those involved, be it soldiers, local militants, medical staff or peaceful locals. The novel relates the story of Private John Bartle's service in the U.S. Army in Al Tafar, Iraq, with his colleagues, Sergeant Sterling and Private Daniel Murphy (Murph). The narration retrospectively moves through Iraq, Germany and the U.S. to portray the context and repercussions of Bartle's experience of war.

Based on the three main periods in the time of disasters, survival psychology in the narrative is analysed in three levels, namely, pre-impact, impact and post-impact periods. Reading the narrative through the lens of survival psychology enables readers to comprehend the behaviour of characters in times of war. The analysis also provides significant insights into the reactions of humans, be it military or otherwise, in the time of danger. Finally, the explication of the narrative allows readers to appreciate the survival experience of the author and subsequently acknowledge the psychological implications of active participation in times of war.

\section{LITERATURE REVIEW}

Unlike other writings that contest the justification and legitimisation of the war in Iraq (Alosman et al., 2018a; Alosman et al., 2018b), The Yellow Birds is seen to reveal truths about war in a way no psychological book or article can (Marzillier, 2013). It can provide psychiatrists what academic psychological statistics cannot, namely, individual soldiers' narratives (Marzillier, 2013). Powers' paramount achievement in The Yellow Birds is his persuasive ability to evoke the psychological damage American soldiers went through in the war in Iraq (Nester, 2013). The novel also portrays melancholies that overarch the lives of local people in the context of war, albeit within a limited narrative space.

Nonetheless, Evers (2012: n.p.) shares that although Powers' novel has 'some fine, uncluttered and understated writing,' it does not heighten war experience, rather distracts it. Evers (2012) also argues that despite Powers' evident talent in writing The Yellow Birds, the novel still lacks the consistency and restraint to fully delivery the promise of importance. Powers' attempt to combine poetic and prosaic styles does not seem to serve the narrative (Evers, 2012). In the same vein, Beauchamp (2017) feels that despite the lyrical strength of Powers' novel and its being a testament to humanist values and traditions, The Yellow Birds ignores the full and terrible grandeur of the war as an independent event.

Many critics acclaim the novel's brilliant appropriation of the war in Iraq as no novel has done before (Eggers, 2013; Marzillier, 2013; Tobar, 2012). Walter (2016), for instance, contends that Powers gives the readers access to the distinctive emotions of war, bridging the gap between 'outsiders' and 'insiders' of war through the memories of the narrator in The Yellow Birds. In the novel's account of the war in Iraq, Bartle becomes a victim of war violence and American social and political deceit (Mann, 2017). The question of guilt pervades the novel through Bartle who is the main character and narrator (Nester, 2013). The guilt felt by Bartle is an 'omnipresent shadow' driven by the awareness of 'the disintegration of any trace of humanity' (Precup, 2017, p. 188). He seems to need an assertion of the possibility of human connectedness against the cruelty of the war (Precup, 2017). Powers' insight into the consequence of war in Iraq is the subject of continuing inspection and examination. Although Powers' book has received much attention from a wide spectrum of literary critics and reviewers in addition to psychologists and psychiatrists, the novel's depiction of war from a survival perspective needs to be addressed. 


\section{SURVIVAL PSYCHOLOGY}

Psychoanalysis avails literary criticism a significant tool to approach literature and since the beginning of the 20th century, it has been employed as a reading tool to provide literary criticisms on works of fiction, particularly on issues of internal conflicts faced by protagonists (Parkin-Gounelas, 2001). Most significantly, Freud's theory of the personality has influenced reading, seeing and the practices of textual criticism and theory (Lauretis, 2008), much in line with what Sigmund Freud foresees as the strength of psychoanalysis (Rabaté, 2014). Seen from another perspective, literature can thus be a valuable source for the clinical practice of psychology (Marzillier, 2007).

Although literature and psychoanalysis are in different disciplines, humanities and psychology, respectively, they are 'enfolded within' one another (Felman, 1977, p. 9). The most recent acceleration in the convergence of the two disciplines has taken place in recent decades (Parkin-Gounelas, 2001), primarily with the development of new fields within the science of psychology. One such an emergent field of psychology is survival psychology, which is concerned with human behaviour before, during and after hazardous situations, including trauma and turbulent experiences (Leach, 1994; Guilbeau, 2014). Powers' 2012 war and post-war narrative, The Yellow Bird, about the psychological complications soldiers face during and after returning from war, is best read within the lens of survival psychology.

In such a trauma-laden environment, those who continue to live can be recognised as survivors who continue to adopt and adapt to the ever-challenging environment (Cairney, 2014; Cyrulnik, 2011; Leach, 2011; Siebert, 2005). Within the survival framework, survival behaviour has two distinct types, namely, intrinsic and extrinsic (Leach, 2011). The former is maintained by the day-to-day routine behaviour within the normal environment. The latter, however, indicates any new behaviours that emerge given the new dramatic circumstances that arise in times of war.

Survival psychology utilises scientific and humanistic approaches to understand how people react in disaster situations, including conflicts related to wars or any perilous situations that threaten personal survival (Guilbeau, 2014). The psychological realities of survival are 'better understood once the architecture or anatomy of a disaster is appreciated' (Leach, 1994, p. 1). Although the nature of catastrophic situations is diverse, a remarkable degree of consistency between such apparently dissimilar events exists (Drabek, 2013; Fletcher \& Lovejoy, 2018). The behaviour of people involved in these life-threatening situations is consistent during these disasters. Leach (1994: p.1) states that such a behaviour 'follows a structural pattern and a pattern which is transferable across different types of disaster.'

To consider survival psychology, survival situations can be divided into three stages, namely, pre-impact, impact, and post-trauma phases (Leach, 1994). First is the pre-impact stage, which occurs just before an actual event; it begins when an imminent threat exists (Fogo, 2017). During the pre-impact period, even though certain threatening situations may occur without warning, leaving no possibility for preparation, other occurrences carry signs of danger that alert people to the likeliness of perilous events. Certain identifiable signals foretell threats and produce feelings of apprehension and anxiety in individuals (Leach, 1994). This phase is further subdivided into two sub-phases, threat and warning. From a psychological perspective, a threat exists as soon as people acknowledge the probability of a disaster (Leach, 1994). People's behaviour during this period is generally characterised by 'inactivity' (Leach, 1994, p. 12). This situation is ineffective as much as taking useful counter measures and making contingency procedures is concerned. A pervasive feeling of personal invulnerability exists that results from the denial of the possibility of a catastrophe (Leach, 1994). Denial reduces anxiety as people reassure themselves that they are not in danger; it can also be perilous as people may not react to dangerous situations in the right time (Robinson \& Bridges, 2011). In 
the warning sub-phase, the imminent danger becomes 'too real' and tangible (Leach, 1994, p. 18). Compared with the previous inactive phase, the warning phase is identified by ineffective over-activity (Leach, 1994). Albeit the behaviour is inappropriate, the most common psychological response characterised during the warning stage is still denial (Drabek, 2012; Leach, 1994).

Second is the impact period, which may or may not be preceded by the pre-impact period (Leach, 1994). Sometimes, a danger strikes whilst people are completely unaware, and it may last from a few seconds or minutes to more than one hour (Fogo, 2017; Leach, 1994). Whether the danger is expected or otherwise, the immediate result of a catastrophe overwhelms the sensory overload as the brain is flooded with sights, sounds, touches, smells and tastes (Leach, 1994). Victims of danger are surrounded by information they can neither process nor comprehend that subsequently causes them to become confused and numb and thus suffer from cognitive dysfunction (Leach, 2011). This period is relatively uncontrollable, and very little can be done in terms of general survival strategies (Fogo, 2017). Even armed soldiers, who are constantly trained to operate under perilous conditions, are vulnerable to consequences. Leach (1994, p. 23) asserts that "No amount of training will entirely remove the psychological response to the "crack-bang" of the first round passing close overhead or the psychological disruption caused by artillery or tank shells exploding nearby and especially behind a person's unit.'

Despite the high risks of health and security during the impact phase (Fogo, 2017), the behaviour of people varies. An identifiable pattern of reactions that is 'consistent throughout many independent studies of disasters' is found (Leach, 1994, p. 24). Leach (1994) divides this pattern into three bands. The first group consists of $10 \%-20 \%$ of people who remain relatively calm during the impact period (Leach, 1994). Few people are extraordinarily quiet and rational whilst remaining clear minded, as Leach $(1994$, p. 24) states, 'They will be able to assess the situation, make a plan and act upon it.' Those who overcome such hazardous situations are regarded to have the so-called 'will-to-live,' as they have confronted death and come through alive whilst others in the same duress have surrendered and died (Leach, 2011; Sherwood, 2009). They can assess situations quickly and accurately and determine their own level of danger (Fogo, 2017; Sherwood, 2009). They use common sense to understand situations and consider alternative reactions (Fogo, 2017; Sherwood, 2009).

The second group comprises $75 \%$ of people who are simply stunned and bewildered (Fogo, 2017; Leach, 1994). Their recognition is considerably diminished, and thinking is difficult. They act in an almost automatic or mechanical manner: "Their field of attention becomes very restricted and visually, they may suffer "tunnel vision" or more correctly, perceptual narrowing. The sense of the passage of time also alters producing a limbo effect which can disrupt and even destroy the carrying out of set plans' (Leach, 1994, p. 24). These people lack the ability to talk about their feelings or emotions. They also have certain physiological reactions, such as sweating, trembling, weakness, nausea, vomiting, urination and defecation (Leach, 1994).

The third group comprises $10 \%-15 \%$ of people (Leach, 1994) whose behaviour exhibits high inappropriateness. In addition to the inefficacy of their reactions, their behaviour may also be counterproductive to the point of accumulating the danger; such behaviours include unrestrained weeping, confusion, screaming and paralyzing anxiety, where people freeze in their places (Leach, 1994). Failure to act or freezing is an impaired response that establishes a closed-loop process and leads to losses in survivable situations (Leach, 2004). Victims sometimes unnecessarily perish because they do not comprehend situations and thus cannot react appropriately (Leach, 2011). However, the most common initial reactions in the impact period are disbelief and denial, and very few people can recognise direct threats of imminent disasters (Drabek, 2012; Leach, 1994). The feeling that 'this will not happen to me' or 'this 
cannot be happening to me' (Leach, 1994, p. 25) is a common reaction. However, akin to freezing under pressure, the body in this stage at times behaves in survival mode (Aten, 2017). When someone in this group hears a loud noise, though harmless, he dives for cover as his body interprets the loud noise as a combat threat (Aten, 2017).

The third is the post-trauma period, which involves survivors who attempt to re-establish their lives when initial dangers are removed (Leach, 1994). People become fully aware of what has happened to them during the phase of impact. Normally, it starts with confusion as people slowly start to recognise the extent of a catastrophe. People gradually return to awareness, reasoning and emotional expression (Leach, 1994) and start to feel fear, resentment, anxiety and anger. People search for and inquire about their family members as family bonds override all other ties (Leach, 1994). Separation from familiar persons and places is a greater stressor than physical danger itself (Mawson, 2005). Generally, an increase in activities is observed, and many people can be temporarily hyperactive. Survivors show an almost childish attitude of dependency in its observation and expression. Such dependency is quite temporary and usually last no more than a day or two (Leach, 1994). The psychological effects can vary as per the extent of disasters and the training and preparation of those involved (Leach, 1994). During this phase, 'the symptoms will now appear to be more psychiatric in nature than psychological. The common symptoms are recurrent dreams about the catastrophe, anxiety, depression and psychosomatic disorders' (Leach, 1994, p. 27). Many people can completely recover, but some may take long to improve, and few can never fully recover in the least (Leach, 1994).

Many survivors show notable capacity to recover after being exposed to traumatic situations (Bisson et al., 2015). However, a significant burden of post-traumatic stress disorder (PTSD) exists (Galea, Nandi \& Vlahov, 2005). 'PTSD is a mental disorder that may develop after exposure to exceptionally threatening or horrifying events' (Bisson et al., 2015). The intensity of trauma and the susceptibility of people interact to affect the possibility of PTSD (Shalev, Liberzon \& Marmar, 2017). PTSD is the most predominant psychopathological consequence of experiencing traumatic events (Shalev, Liberzon \& Marmar, 2017). The degree of exposure to a catastrophe is possibly the most important factor for the development of PTSD (Galea, Nandi \& Vlahov, 2005). People who are direct victims of a disaster have a great possibility of having PTSD (Galea, Nandi \& Vlahov, 2005). The severity of the disaster and the level of individual involvement in the disaster can potentially aggravate PTSD symptoms.

Many symptoms of people with PTSD can affect their psychological and physical life to different degrees. Experiencing wartime atrocities is predictive of increased guilt, depression and suicidal ideation after controlling for overall combat exposure (Dennis et al., 2016). PTSD degree of severity has a larger mediational effect than combat-related guilt (Dennis et al., 2016). People with PTSD are increasingly at risk of suffering poor physical health (Bisson et al., 2015). Indicators include persistent disturbing memories and alterations in perceptions and moods (Bisson et al., 2015).

The central symptoms of PTSD are 'the persistence of intense, distressing and fearfully avoided reactions to reminders of a triggering event, alteration of mood and cognition, a pervasive sense of imminent threat, disturbed sleep and hypervigilance' (Shalev et al., 2017, p. 2459). For those diagnosed with PTSD, the severity of indicators varies over time; symptoms increase when stimulated by cooccurring stressors, illness and life transitions in a safe environment (Shalev, Liberzon \& Marmar, 2017). The appropriate processing of circumstantial evidence allows people to freeze or flee. Therefore, people diagnosed with PTSD are hypervigilant; they behave inappropriately to situations and misread cues as threatening despite a safe context (Shalev, Liberzon \& Marmar, 2017).

In war, exposure to lethal combat experiences has a negative impact on the mental health of all those involved (Donoho et al., 2017). American military involvement in Afghanistan and 
Iraq has caused an increased worry for the long-term mental health of service members (Donoho et al., 2017). Soldiers who experience direct and indirect engagements with hostile forces can have high traumatic stress levels (Donoho, 2017). Although most soldiers remain resilient even after experiencing combat, combat deployments have serious consequences for mental health (Donoho et al., 2017). Even trained soldiers can suffer in the aftermath of their service in combat zones.

In this paper, Powers' novel can be analysed according to the three major periods of impact, namely, pre-impact, impact and post-impact periods. Firstly, the author's portrayal of the pre-impact period, which takes place just before a dangerous situation, is investigated. Secondly, the impact period is analysed to examine the psychological implications of the author's representation of time of disasters, that is, when lives are being threatened. Lastly, the post-impact period illustrates the psychological repercussions of the perilous experiences on the lives of those involved.

\section{ANALYSIS}

\section{PRE-IMPACT PERIOD}

We analyse the psychological implications of the novel's illustration of the time that precedes a disaster. Although living in the dangerous context of war, people do not always take necessary precautions. Whilst Bartle and Murph are sitting by a wall and having a conversation with Malik, the Iraqi translator, he stands up even though Murph warns him, 'Careful, big guy. You're gonna get silhouetted' (Powers, 2012, p. 10). Even though Bartle and Murph do not see the over-in-a-flash act, they instantly see Malik's 'blood' on their uniforms (p. 11). He gets killed when he could have easily avoided that. Certain people fail to respond to impending threats because of denial behaviours (Robinson \& Bridges, 2011). This state of denial can be psychologically protective and lead certain people to reduce anxiety as people ignore cautions to reassure themselves that they are safe (Robinson \& Bridges, 2011). Even though Malik recognises the hazardous situation he is in and hears the sound of nearby shooting, denial leads him to disregard Murph's cautions. By denying the actuality of the surrounding danger, Malik exposes himself to danger and consequently loses his life. As illustrated in Malik's case, certain people, though cautioned, deny and ignore the impending danger.

When the looming danger becomes too real, and the threat becomes evident, people overreact ineffectively, and their behaviour is mostly inappropriate (Leach, 1994). As a car drives towards their platoon, Bartle sees through his scope an elderly man and woman inside (Powers, 2012). Before he could yell at Sterling and warn him against firing at them, Sterling opens fire at the approaching car until the holes made by the gun machine 'funnel[s] light' (p. 22). Although he cannot clearly identify them, he overreacts to this situation when no evident threat is found.

\section{IMPACT PERIOD}

We now illustrate the time when a disaster is taking place with regard to survival psychology for soldiers and civilians. In the midst of war, Bartle recounts how an armed Iraqi man ran behind a low wall 'astonished to be alive, his weapon cradled in his arms' (Powers, 2012, p. 20). The man does not run away, 'keeps going' (p. 20), as he looks left and right in bewilderment. He then gets shot. In the midst of such deadly clashes, the man fails to act properly and save his life though he is supposed to be trained or at least is expected to be in such situations. Even though the man could have run away to a safe place or used his arms to cover up his escape, he exposes himself to danger and becomes an easy target. In survival situations, people are surrounded by much information they can neither process nor understand 
(Leach, 1994). People become confused and numb as their cognitive function becomes impaired under life-threatening circumstances (Leach, 2011). Even soldiers who are trained to be in dangerous battle conditions become confused sometimes under the impact of dangerous situations because no training can remove the psychological disruption in such circumstances (1994, Leach).

Another anecdote where imminent danger seems to dominate the narrative takes place in the neighbourhood of the medical evacuation centre in Al Tafar. Under mortar attacks, Bartle declares, 'I gave up, surrendered, whatever, I was gone' (Powers, 2012, p. 167). He aimlessly moves whilst obsessed with 'fear' (p. 168). His eyes are 'welled with tears' as he 'wet[s]' his pants; he screams 'sobbing with each step; he then hides in a ditch of dirty water where only his 'nose and eyes [are] above the level of water' (p. 168). Although Bartle is a U.S. Army soldier, who has gone through excessive training for such life-threatening situations, he seems perplexed and fear-driven under the mortar attack. He chooses to flight, a strategy utilised when people are under lethal threats (Leach, 2004; Habben, 2015).

Soldiers seem to lose the ability to pronounce their feelings when a combat occurs. Bartle wonders about his frame of mind when a combat takes place and tries to understand 'the tremble' that takes over his thighs and makes his fingers 'slick and clumsy' (Powers, 2012, p. 93). He admits that Murph has come close to describing it by likening it to 'a car accident' where you feel 'pretty helpless actually' (p. 93). He adds that in these situations, soldiers feel that they do not have the power to do anything about it, 'like that split second in the car wreck, except for here, it can last for goddamn days' (p. 93). Bartle illustrates how in such deadly situations, his body 'couldn't sustain the tightened muscles and sweat. But it didn't end, so I tried not to pay attention to it' (p. 93). Powers delicately depicts '[h]elplessness in the face of imminent death' (Marzillier, 2013, p. 349). Trembling, sweating and weakness are some of the physiological reactions during the impact period (Leach, 1994). Although soldiers expect to be in dangerous conditions, the instantaneous result of combat is an overpowering of the senses (Leach, 1994). In such situations, most people lose the ability to express their feelings or sentiments (Leach, 1994).

After Bartle and his colleagues witness the death of a Private in front of their eyes, Sterling confirms the fact that almost all soldiers normally do not say anything before death, except for one soldier. After Bartle's insistence to know what that soldier said before his death, Sterling, reluctantly tells him that the soldier was 'crying' (Powers, 2012, p. 120); the dying soldier says, "'I'm fucking dying, right?" [. . . A And he kept crying harder and then he stopped;' the Private asks Sterling, "Hey, man, check if I shat my pants." Then he was dead' (p. 120). When confronted with life-threatening situations, certain people in extreme cases react to danger by vomiting, urination and defecation (Leach, 1994).

\section{POST-IMPACT PERIOD}

In this last section, the post-disaster psychological repercussions, as demonstrated in the novel, are examined. After being in the midst of death and life-threatening experiences, certain soldiers become estranged as they try to escape the horrible realities of war. Bartle and his colleagues notice Murph's newly 'strange behaviour' (Powers, 2012, p. 155). When Bartle discusses Murph's absence with Sterling, Sterling tells him that getting used to 'the fact that Murph's a dead man' is better for him (p. 155). Bartle finds Murph in the medical evacuation station near their platoon. Under the shade of a wall, Murph is waiting for something. An injured soldier in grave condition is taken out of a chopper (helicopter) into the station and there appears a medic girl. Bartle notices Murph's interest in the girl and asks him if she is the reason behind his being in the station. Murph answers that is what he has been doing. In the midst of the recent scenes of death they have witnessed, Murph tries to escape these realities 
and finds a way for a peaceful life. War repercussions seem to have a great influence on Murph's psychological state as he begins to frequent the medical station. After people's survival has been at stake in an almost daily basis, people attempt to restart their normal life (Leach, 1994). Murph's frequent visits to the medical station are his last attempt to reclaim a normal life.

Through the character of Murph, war is illustrated as a forceful power, which exhausts the psyche of its own citizens and soldiers. After what he has seen in Iraq, Murph 'surrender[s] fully to the war' (Powers, 2012, p. 80). He is seen by local Iraqi people whilst walking 'naked' with his face and hands 'tanned' by the sun (p. 195). 'He walk[s] as a ghost, his feet and legs bleeding from his walk through the wire and detritus' (p. 195). Murph walks to the Iraqi people and leaves 'bloody footprints' on road dust (p. 196). After he reaches them, he raises 'his head absently to the sky' and pauses (p. 196). He shuffles 'his feet at them and sway[s] gently from side to side, his body flecked in sweat. He show [s] no awareness of their presence [ . ;] a quiet stroll through an enormous museum gallery' (p. 196). The Iraqi people attempt to break his 'stance' by screaming and pleading, but Murph's eyes catch 'the shape of an old beggar' ( $p$. 196). Murph loses his psychological faculties and surrenders to psychosis. Some war survivors suffer from psychiatric disorders, such as psychosis (Leach, 1994). Similar circumstances that Murph has experienced have taken place in Iraq with some American soldiers (Powers, 2013). After living in a relatively safe environment, soldiers find themselves exposed to shocking experiences in an excessively hazardous environment (Habben, 2015).

As illustrated in Powers' novel, melancholy is one of the consequences of war. On his way back to the United States, Bartle spends a day in Rhineland-Palatinate, Germany, where he walks until he enters a church (Powers, 2012). A priest approaches him and tells him that he looks 'troubled' and 'burdened' (p. 58). Depression is one of the common post-trauma symptoms (Leach, 1994). Bartle leaves the church and walks aimlessly until he reaches a night club. In the club, he asks the bargirl for 'whiskey' (p. 64). After he gets drunk, he wakes up to find himself in bed upstairs. As the bargirl takes care of him, she tells him that '[y]ou are all [American soldiers] so sad' (p. 71). Bartle looks gloomy even though such a journey back home should have made him happy. Sterling also visits the same nightclub, gets drunk and beat the bargirl until she bleeds. Powers illustrates the soldiers' state of mind after experiencing war as depressed. In an interview, Powers (2013) declares that war veterans experience drunkenness, homelessness and rash of suicide. Veterans involved in deadly combats are at an increased risk of suicide (Bisson et al., 2015).

One of the post-impact consequences of war is being overwhelmed by its memories. Although Bartle is back in the United States, he imagines that 'the ghosts of the dead filled the empty seats of every gate' in the airport (Powers, 2012, p. 104). He sees 'boys destroyed by mortars and rockets and bullets and IEDs to the point that when we tried to get them to a medevac, the skin slid off or limbs barely held in place detached' (p. 104). He thinks that those boys and their dreams are killed by war. Although Bartle is at home, he remains preoccupied by the horrible scenes of death he has witnessed in Iraq. Images of death still dwell in his mind. He seems distracted from the present with these past memories. After returning from war, many soldiers return with images that cannot be obliterated from their minds (Habben, 2015).

The Yellow Birds is largely about an unrecovered loss or death (Mann, 2017). Bartle is preoccupied with insistent images from the war whilst at home (Powers, 2012). Despite his mother's consecutive attempts to engage him in social life, he prefers to stay alone in his room and wander lonely for days in the woods (Powers, 2012). He becomes totally isolated from his old friends. In an interview, Powers (2013) refers to the suffering of soldiers when they come home with the insistent horrible memories. No one can go to war and escape the physical or psychological repercussions. When people come from war, they are psychologically damaged (Powers, 2013). Persistent distressing memories and changes in mood are some of the 
indicators of PTSD (Bisson et al., 2015). As Bartle experiences an incredible sense of dislocation and estrangement, he completely withdraws from everyone as he struggles to cope with PTSD (Nester, 2013). Similar to many veterans, Bartle is destined to live with PTSD in the aftermath of war.

In the airport, Bartle relates how travellers embrace and thank him for his service as an American soldier. However, he is only aware of his mother; as if he has 'somehow been returned to the singular safety of the womb, untouched and untouchable to the world outside her arms around my slouching neck' (Powers, 2012, p. 109). After disasters, familial bonds outweigh all other ties (Leach, 1994). What matters for Bartle when he is home is his own safety after experiencing wartime atrocities. He is heedless to those who appreciate his status as an American soldier returning home after his service in Iraq. He only wants to feel safe again after his life has been endangered in war.

In Germany, before heading to the United States, Bartle describes his state of mind and body whilst in a taxi.

\begin{abstract}
As I looked out onto the trees that edged the road, my muscles tensed, and I began to sweat. I knew where I was: a road in Germany, AWOL, waiting for the flight back to the States. But my body did not: a road, the edge of it and another day. My fingers closed around a rifle that was not there. I told them the rifle was not supposed to be there, but my fingers would not listen, and they kept closing around the space where my rifle was supposed to be, and I continued to sweat, and my heart was beating much faster than I thought reasonable. (Powers, 2012, pp. 53-54)
\end{abstract}

Marzillier (2013) expresses his admiration for Powers' accurate description of an intrusive body memory during the post-trauma period. After being endangered in circumstances of war for a long time, Bartle's body and state of mind are still set within the realms of war despite the fact that he is thousands of miles away from Iraq. The bodies of certain soldiers behave as if they are still in survival mode after returning home (Aten, 2017). Those diagnosed with PTSD sometimes become hypervigilant and stimulated in a safe environment (Shalev, LIberzon \& Marmar, 2017). Marzillier (2013) contends that reading The Yellow Birds can be helpful to know about the comorbidity of PTSD in soldiers. Powers' novel gives a vivid sense of what the trauma of war is like and brings readers the painful truths about the harm trauma does (Marzillier, 2013). Surviving wartime atrocities does not always guarantee psychological survival. Exposure to deadly combats in war can have severe psychological complications.

\title{
CONCLUSION
}

As shown in this paper, survival psychology illustrates the behaviour of civilians and combatant characters before, during and after war. Regardless of the degree of training received by professional soldiers, as exemplified in the American characters, some cannot to cope with war and behave properly; they are susceptible to passivity in certain situations as illustrated in Murph's case. Although Bartle survives dangerous combats, he suffers for years with PTSD. Civilians seem to be more vulnerable and less immune in this environment. Malik's denial during the pre-impact period leads to his death.

Reading Powers' novel from the angle of survival psychology enables us to gain additional insight into the behaviour of characters within the context of war. Simultaneously, we can comprehend the psychological implications of being at war because the novel has been written by a war veteran. Man-made disasters, such as wars, appear to affect more lives than natural catastrophes. The psychological consequences of war can be far reaching. Sometimes, they out-live war and out-number its physical casualties. Situating literary works within their psychological contexts can advance our comprehension and appreciation of these texts. Doing 
so provides the readership with another lens to fathom certain unidentified parts in the human psyche. Thus, interdisciplinary research on works of fiction can open new horizons for the involved fields and subsequently position researchers from the field of humanities to be at the forefront of the conversation on war and its effects on humanity.

\section{ACKNOWLEDGEMENT}

This research was funded by UKM research grant (Research code: GUP-2016-067).

\section{REFERENCES}

Alosman, M. I. M., Raihanah, M. M. \& Hashim, R. S. (2018a). Differentiation and imperfectionality in John Updike's Terrorist. 3L: The Southeast Asian Journal of English Language Studies. Vol. 24(2), 58-70.

Alosman, M. I. M., Raihanah, M. M. \& Hashim, R. S. (2018b). Architectures of enmity in Andre Dubus III's The Garden of Last Days. GEMA Online ${ }^{\circledR}$ Journal of Language Studies. Vol. 18(4), 251-264.

Aten, J. D. (2017). Wired for survival: Understand and harness your body's natural stress response when it counts. Retrieved August 12, 2018 from https://www.psychologytoday.com/us/blog/heal-and-carry/201706/wired-survival

Beauchamp, S. (2017). The detached literature of remote wars. American Affairs. Vol. 1(3), 184-96.

Bisson, J. I., Cosgrove, S., Lewis, C. \& Robert, N. P. (2015). Post-traumatic stress disorder. BMJ (Clinical research ed.). Retrieved December 12, 2018 from https://www.ncbi.nlm.nih.gov/pmc/articles/PMC4663500/

Cairney, J. (2014). The Importance of Being: Observations through Anecdotage. Edinburgh: Luath Press.

Cyrulnik, B. (2011). Resilience: How Your Inner Strength Can Set You Free from The Past. London: Penguin.

Dennis, P. A., Dennis, N. M., Van Voorhees, E. E., Calhoun, P. S., Dennis, M. F. \& Beckham, J. C. (2016). Moral transgression during the Vietnam War: a path analysis of the psychological impact of veterans' involvement in wartime atrocities. Anxiety, Stress, and Coping. Vol. 30(2), 188-201.

Donoho, C. J., Bonanno, G. A., Porter, B., Kearney, L. \& Powell, T. M. (2017). A Decade of war: Prospective trajectories of posttraumatic stress disorder symptoms among deployed US military personnel and the influence of combat exposure, American Journal of Epidemiology. Vol. 186(12), 1310-1318.

Drabek, T. E. (2012). Human System Responses to Disaster: An Inventory of Sociological Findings. New York: Springer Science \& Business Media.

Drabek, T. E. (2013). The Human Side of Disaster. New York: CRC Press.

Eggers, D. (2013). 'We tend to look everywhere but the mirror'. The Guardian. Retrieved September 23, 2018 from https://www.theguardian.com/books/2013/jan/26/daveeggers-hologram-king-interview

Evers, S. (2012). The Yellow Birds, By Kevin Powers. Independent. Retrieved January 29, 2018 from https://www.independent.co.uk/arts-entertainment/books/reviews/theyellow-birds-by-kevin-powers-8160317.html

Felman, S. (1977). To open the question. Yale French Studies, (55/56), 5-10.

Fletcher, C. V. \& Lovejoy, J. (2018) Natural Disasters and Risk Communication: Implications of the Cascadia Subduction Zone Megaquake. London: Lexington Books. 
Fogo, W. R. (2017). Understanding Factors Related to Surviving a Disaster: The Survival Attitude Scale. Unpublished PhD dissertation, Bowling Green State University, Ohio, USA.

Galea, S., Nandi, A. \& Vlahov, D. (2005). The Epidemiology of Post-Traumatic Stress Disorder after Disasters. Epidemiologic Reviews. Vol. 27(1), 78-91.

Guilbeau, C. (2014). Survival psychology according to John Leach. Retrieved April 17, 2018 from https://udallas.edu/udjs/departments/psychology/2013-2014/survivalpsychology.php

Habben, C. J. (2015). Recent wars and the psychology of men: Beyond the Polemics. Retrieved September 10, 2018 from http://division51.net/clinicians-corner/recent-wars-and-thepsychology-of-men-beyond-the-polemics/

Kakutani, M. (2012). Soldiering amid hyacinths and horror. New York Times. Retrieved May 19, 2018 from https://www.nytimes.com/2012/09/07/books/the-yellow-birds-bykevin-powers.html

Lauretis, T. D. (2008). Freud's Drive: Psychoanalysis, Literature and Film. New York: Palgrave.

Leach, J. (1994). Survival Psychology. Houndmills: Macmillan.

Leach, J. (2011). Survival Psychology: the won't to live. The Psychologist. Vol. 24(1), 26-29.

Mann, J. (2017). Mapping memory: Moving between trauma and terror in The Yellow Birds. Critique: Studies in Contemporary Fiction. Vol. 58(4), 340-350.

Mantel, H. (2012). Writers (and rockers) on their books of the year. The Times. Retrieved May 9, 2018 from https://www.thetimes.co.uk/article/writers-and-rockers-on-their-booksof-the-year-vcww2536pds

Marzillier, J. (2007). Special section: What can clinical psychologists learn from reading novels? Clinical Child Psychology and Psychiatry. Vol. 12(3), 393-401.

Marzillier, J. (2013). Eye on fiction: The Yellow Birds. The Psychologist. Vol. 26(5), 348-349.

Mawson, A. R. (2005). Understanding mass panic and other collective responses to threat and disaster. Psychiatry: Interpersonal and biological processes. Vol. 68(2), 95-113.

Mitchell, D. (2012). By the Book. New York Times. Retrieved August 28, 2018 from https://www.nytimes.com/2012/10/21/books/review/david-mitchell-by-the-book.html

Nester, T. (2013). Book review: The price of war. Bridgewater Review. Vol. 32(1), 39-40.

Parkin-Gounelas, R. (2001). Literature and Psychoanalysis: Intertextual Readings. New York: Palgrave.

Powers, K. (2012). The Yellow Birds. New York: Little, Brown and Company.

Powers, K. (2013). The Yellow Birds. Kevin Powers, Perth Writers Festival. Retrieved May 7 , 2018 from https://www.youtube.com/watch?v=VL7IICN4Esg

Precup, A. (2017). Reversing Absence. The Explorations of Memory in The Yellow Birds By Kevin Powers. Studia Ubb Philologia. Vol. LXII (1), 173 - 190.

Rabaté, J-M. (2014). Freud's textual couch, or the ambassador's magic carpet. In L. Marcus \& A. Mukherjee (Eds.), A Concise Companion to Psychoanalysis, Literature, And Culture (pp. 103-121). West Sussex: Wiley Blackwell.

Robinson, S. \& Bridges, N. (2011). Survival - mind and brain. The Psychologist. Vol. 24(1), 30-33.

Shalev, A., Liberzon, I. \& Marmar, C. (2017). Post-traumatic stress disorder. New England Journal of Medicine. Vol. 376(25), 2459-2469.

Sherwood, B. (2009). The Survivors Club: The Secrets and Science that Could Save Your Life. UK: Penguin.

Siebert, A. (2005). The Resiliency Advantage: Master Change, Thrive Under Pressure, and Bounce Back from Setbacks. San Francisco: Berrett-Koehler Publishers. 
Tobar, H. (2012). Kevin Powers' haunting Iraq war novel. Los Angeles Times. Retrieved June 7, 2018 from http://articles.latimes.com/2012/nov/10/entertainment/la-ca-jc-kevinpowers-20121111

Walter, A. (2016). "What it felt like": Memory and the sensations of war in Vergil's Aeneid and Kevin Powers' The Yellow Birds. Thersites. Vol. 4(2016), 275-312.

\section{ABOUT THE AUTHORS}

M. Ikbal M. Alosman (Ph.D) is an Assistant Professor of English language and literature at the English Language and Literature Department, Avrasya University, Turkey. His research interests include postcolonial studies, geopolitics and war in literature and psychoanalysis.

Raihanah M. M. (Ph.D) is an associate professor of literary studies at the Faculty of Social Sciences and Humanities, National University of Malaysia. She has researched, supervised and published in the area of Muslim diaspora and minority fiction. She teaches comparative literature and Malaysian Literature in English at the graduate level. 